\title{
Holocene hydroclimate in the Southeastern United States during abrupt climate events: evidence from new speleothem isotopic records from Alabama
}

Martín Medina-Elizalde ${ }^{1 *}$, Stefan Perritano ${ }^{2}$, Matthew DeCesare ${ }^{2}$, Josué Polanco-Martinez ${ }^{3}$, Gabriela Serrato-Marks ${ }^{4}$, David McGee ${ }^{4}$, Fernanda Lases-Hernandez ${ }^{5}$.

1. Department of Geosciences, University of Massachusetts, Amherst.

2. Department of Geosciences, Auburn University, Alabama.

3. DeustoTech-Deusto Institute of Technology, Faculty of Engineering, University of Deusto, Bilbao, Spain.

4. Department of Earth, Atmospheric and Planetary Sciences, Massachusetts Institute of Technology

5. Department of Chemistry (Facultad de Química), National Autonomous University of Mexico (UNAM), Sisal, Yucatán, Mexico.

*Corresponding author: Martín Medina-Elizalde, Email: mmedinaeliza@umass.edu

\section{Abstract}

We present new high-resolution absolute-dated stalagmite $\delta^{18} \mathrm{O}$ and $\delta^{13} \mathrm{C}$ records from Alabama, southeastern United States (SE US), spanning the last 12 thousand years (ka). A local

relationship between annual rainfall amount and its amount-weighed $\delta^{18} \mathrm{O}$ composition exists on interannual timescales, driven mostly by an amount effect during summer and spring seasons, and by an isotopically depleted composition of fall and winter precipitation. Based on a novel interpretation of modern rainfall isotopic data, stalagmite $\delta^{18} \mathrm{O}$ variability is interpreted to reflect the relative contribution of summer and spring precipitation combined relative to combined fall and winter precipitation. Precipitation amount in the SE US increases during the Younger Dryas, the $8.2 \mathrm{ka}$ and Little Ice Age abrupt cooling events. High precipitation during these events reflects enhancement of spring and summer precipitation while the contribution of fall and winter rainfall remained unchanged or decreased slightly. Results from this study support model simulation results that suggest increased precipitation in the SE US during Atlantic Meridional Overturning Circulation (AMOC) slowdown/shutdown (LeGrande et al., 2006; Renssen et al., 2002; Vellinga and Wood, 2002). In association with Northern Hemisphere mid-latitude cooling 
32 from the Early to mid-Holocene, annual precipitation in the SE US decreases, a pattern

33 distinctive from that observed during abrupt cooling events related to AMOC shifts. Long-term

34 hydroclimate change in the SE US is likely sensitive to summer insolation reduction as inferred

35 for other tropical and subtropical regions. This study has implications for our understanding of

36 the sensitivity of subtropical hydroclimate to factors both internal and external to the climate

37 system in a warmer climate.

38 1. Introduction

39 The evolution of human societies and ecosystems are intimately related to the degree of

40 climate stability over time at a regional scale (IPBES, 2019; Ipcc, 2014). The Intergovernmental

41 Platform on Biodiversity and Ecosystem Services (IPBES) estimates that within the next three

42 decades 1 million species are threatened with extinction, and it highlights temperature and

43 hydroclimate change as chief driving factors (IPBES, 2019). Large uncertainty remains,

44 however, regarding our understanding of past hydroclimate variability and its underlying drivers,

45 and therefore also, in our capacity to predict the future. Considerable disagreement among state-

46 of-the-art climate model predictions of precipitation for the end of this century underlines the

47 need to better understand the drivers of hydroclimate variability to help improve the climate

48 forecast (Anandhi and Bentley, 2018).

49 A potential driver of abrupt hydroclimate change relates to climate reorganizations associated

50 with slowdown or complete shutdown of the Atlantic Meridional Overturning Circulation

51 (AMOC). This circulation system is thought to be a key tipping point of the Earth's climate

52 system and seems to already be responding to increasing anthropogenic climate forcings

53 (Collins et al., 2019). The potential impacts of AMOC shifts on Northern Hemisphere

54 hydroclimate remain unclear, however. The historical hydroclimate record remains too short and 
55 fragmented to help validate long-term climate model simulations. Thus, model studies rely on

56 the few existing paleoclimate records to assess their performance simulating climate change

57 triggered by abrupt ocean circulation changes (Dahl et al., 2005; Otto-Bliesner and Brady, 2010;

58 Vellinga and Wood, 2002).

59 Hydroclimate variability in the Southeastern United States (SE US) over the Holocene

60 remains poorly understood and model predictions for the end of this century are highly variable,

61 ranging from regional changes of -30 to $+35 \%$ (Anandhi and Bentley, 2018). The possibility that

62 SE US hydroclimate could respond to abrupt climate change resulting from AMOC shifts exists

63 but remains to be examined with empirical observations.

64 The YD (12.8-11.8 ka) (Rasmussen et al., 2006), the $8.2 \mathrm{ka}$ (Thomas et al., 2007) and the

65 Little Ice Age (LIA, C.E. 1400-1900) (Matthes, 1939) cooling events are hypothesized to be in

66 association with AMOC slowdown/shutdown (Broecker et al., 1989), and they provide a testbed

67 to examine subtropical hydroclimate responses to ocean thermohaline circulation shifts.

68 Paleoclimate and model results support the hypothesis that thermohaline circulation changes

69 triggered the YD and 8.2 ka cooling events (Bard et al., 2000; Lea et al., 2003; LeGrande et al.,

70 2006; Peterson and Haug, 2006; Renssen et al., 2002), and were associated with the LIA (Lund

71 et al., 2006). The extent to which these climate oscillations propagated beyond the North Atlantic

72 high-latitudes and affected subtropical hydroclimate, particularly within the SE US, remains

73 poorly known.

74 There are currently very few paleoclimate records from the SE US that cover the critical time

75 intervals during which ocean thermohaline circulation shifts have been recorded. Available

76 paleoenvironmental records for this region (Goman and Leigh, 2004; Grimm et al., 1993)

77 suggest a pattern of Holocene hydroclimate that does not seem to agree with observations from 
78 the North Atlantic over these critical intervals (Grimm et al., 2006). Furthermore, climate model-

79 hosing experiments produce hydroclimate results for the North Atlantic region that are model

80 dependent and strongly contingent upon the duration, magnitude and location of freshwater

81 forcing (Collins et al., 2019; Otto-Bliesner and Brady, 2010).

82 Stalagmite $\delta^{18} \mathrm{O}$ records from the North Atlantic offer a unique opportunity to reconstruct the

83 long-term history of precipitation variability from interannual to millennial timescales in low and

84 mid-latitudes (Aharon and Dhungana, 2017; Medina-Elizalde et al., 2017). Currently, there are

85 only two stalagmite high-resolution climate records available from the SE US region covering

86 the Holocene time interval; one from Alabama spanning from 6 ka to $\sim 1$ ka BP (Aharon and

87 Dhungana, 2017) and another from West-Central Florida, spanning from $6.6 \mathrm{ka}$ to $4.6 \mathrm{ka} \mathrm{BP}$

88 (Pollock et al., 2016). These high-resolution records reveal novel information about decadal and

89 multidecadal hydroclimate variability in the SE US but do not span the critical YD, $8.2 \mathrm{ka}$, and

90 LIA cooling intervals to enable assessing the regional impact of ocean thermohaline shifts.

91 In this study we present a hydroclimate record based on stalagmite $\delta^{18} \mathrm{O}$ and $\delta^{13} \mathrm{C}$ timeseries

92 from the SE US that span the last $\sim 12$ ka and allow us to examine subtropical climate responses

93 to high-latitude climate change forced by thermohaline circulation shifts. There is an interest in

94 determining the actual geographical extent of the YD, $8.2 \mathrm{ka}$ and LIA events beyond the circum-

95 North Atlantic region, especially if climate proxy records representing these events are to be

96 used in helping validate models of thermohaline circulation shifts, in the context of potential

97 changes in deep water formation during the Anthropocene (Collins et al., 2019). 
2. Methods

101 2.1. Study Area

102 In 2017 we retrieved an inactive stalagmite specimen (34 cm long) named War Eagle (WE)

103 from an isolated cave chamber within War Eagle (WE) cave located in Jackson County,

104 Alabama (Fig. 1 and Fig. S1). This cave is located on private property and is only accessible for

105 half a year, when hunting season is off. WE cave has only one entrance requiring a $41 \mathrm{~m}$ rappel.

106 The cave is hosted within the Bangor Limestone and the thickness of the epikarst where the

107 stalagmite was found is estimated to be between 30 and $35 \mathrm{~m}$. The soil on the cave's exterior

108 surface is scarce and the topography is categorized as stony colluvial, rockland limestone, and

109 rockland sandstone (United States Department of Agriculture).

110

111 2.2. Local and regional climatology

112 Mean annual precipitation in the locality of WE Cave is 1,446 $\mathrm{mm}$ and mean annual

113 temperature is $15^{\circ} \mathrm{C}(1981-2010$, NOAA's weather station in Scottsboro, AL., 34.6736N,

114 86.0536W). Precipitation shows almost no seasonality, with the lowest monthly rainfall amount

115 typically observed in the month of October and the highest in December (Fig. S2). Monthly

116 temperature variations range from the lowest in January $\left(4^{\circ} \mathrm{C}\right)$ to the highest in July $\left(26^{\circ} \mathrm{C}\right)$

117 (ncdc.noaa.gov). Alabama like many other locations in the interior southeast has nearly the same

118 amount of precipitation in the warm season as in the cool season. Regional winter precipitation

119 amount comprises the largest portion of the annual budget (29\%), followed by spring and

120 summer ( $25 \%$ each) and lastly fall ( $20 \%$ ) (data from 2005 to 2015$)$. Despite these long-term

121 averages, in recent years summer precipitation has often been greater than other seasons (data 
122 from Tuscaloosa, Alabama, 2005-2015) (Dhungana and Aharon, 2019; Lambert and Aharon, 123 2010).

124 Spatial correlation analyses of the instrumental record of monthly precipitation (from

1251901 to 2013) across the SE US, Caribbean and Gulf of Mexico regions relative to the

126 precipitation record from Alabama, suggest coherent in-phase variability within much of the SE

127 US, and a weak anticorrelation with precipitation variability in the broader Caribbean region

128 (Fig. 1). Anticorrelation reflects the underlying climate dynamics driving seasonal precipitation

129 variability in these regions. Minor precipitation seasonality characterizes the SE US, whereas

130 monsoonal-style seasonality is typical in the broader Caribbean (Karmalkar et al., 2011). End of

$13121^{\text {st }}$ century climate projections suggest contrasting climate responses of these regions as

132 radiative forcing from greenhouse gases increases (Collins et al., 2013).

133 The spatial and temporal pattern of summer precipitation in the SE US is influenced by

134 convective systems (Baigorria et al., 2007), synoptic-scale systems such as tropical cyclones , 135 and large-scale circulation changes (e.g. (Li et al., 2013) and references therein). During the 136 spring and winter seasons mid-latitude cyclones advect moisture from the Gulf of Mexico and

137 North Atlantic into this region (Keim, 1996). The subtropical North Atlantic ocean, the Mexican

138 Caribbean and the Gulf of Mexico regions represent the main source of year-round moisture for 139 precipitation in large areas of the continental US and particularly of the SE US (Gimeno et al., 140 2012). Li et al., (2013), examining multiple reanalysis datasets find that the North Atlantic

141 Subtropical High western ridge position is a primary regulator of interannual variation of

142 moisture transport to the SE US and that dynamical processes (atmospheric circulation) are the 143 main control on interannual variations in precipitation. 


\subsection{Cave Monitoring}

WE cave monitoring was established in order to better understand cave environmental

147 conditions, particularly temperature and relative humidity; both factors affect the isotopic

148 fractionation between drip water and stalagmite calcite. Two ONSET-HOBO instruments were

149 placed inside the chamber where the WE stalagmite was retrieved, from October 2018 to

150 October 2019. Monitoring results indicate WE cave remained at or near saturation conditions

151 (RH 100\%) and was thermally stable year-round with a constant temperature of $14.7^{\circ} \mathrm{C}$, thus

152 very close to local mean surface air temperature. These conditions favor isotopic equilibrium

153 between calcite and drip water. Observed cave air thermal stability indicates that it is in thermal

154 equilibrium with outside air temperature and thus responds to persistent air surface temperature

155 change and not seasonal variability. We collected water at one drip site over the course of one

156 year (i.e. from October 2018 to October 2019). Two six-month cumulative water samples yielded

157 the same isotopic values $\left(\delta^{18} \mathrm{O}=-5.9 \%\right.$ ) similar to the amount-weighted $\delta^{18} \mathrm{O}$ composition of

158 rainfall typically observed in Tuscaloosa (more details below). This indicates that drip water

159 integrates several months and likely more than one year of precipitation amount and that surface

160 and cave evaporative processes are not expected to significantly alter drip water $\delta^{18} \mathrm{O}$, similar to

161 what it is observed in a cave in the Yucatan Peninsula, across the Gulf of Mexico (Lases-

162 Hernández et al., 2019) .

163

\section{2.4. Chronology}

165 The WE stalagmite time scale was determined with $22 \mathrm{U} /$ Th dates (Table S1 and Fig. S3),

166 following the methods by (Cheng et al., 2013). Calcite powders weighing 50 to $130 \mathrm{mg}$ were

167 combined with a calibrated ${ }^{229} \mathrm{Th}-{ }^{233} \mathrm{U}_{-}{ }^{236} \mathrm{U}$ tracer solution, dissolved, and purified through iron 
168 co-precipitation and anion exchange columns based on the methods of Edwards et al (1987)

169 (Edwards et al., 1987). U-Th isotopic measurements were conducted on a Nu Plasma II-ES

170 multi-collector inductively coupled plasma mass spectrometer (MC-ICP-MS) at the

171 Massachusetts Institute of Technology. Analyses were conducted in static mode, with the minor

172 isotopes $\left({ }^{234} \mathrm{U}\right.$ and $\left.{ }^{230} \mathrm{Th}\right)$ measured on a secondary electron multiplier, and all other isotopes

173 measured on Faraday cups. U analyses were bracketed by analyses of standard CRM112a, and

174 Th analyses were bracketed by an in-house ${ }^{229} \mathrm{Th}-{ }^{230} \mathrm{Th}-{ }^{232} \mathrm{Th}$ standard. All dates are corrected

175 for instrument background, tailing, mass bias, SEM yield, contributions from impurities in the

176 spike, and chemistry blanks using an offline data reduction procedure. All errors of isotopic data

177 and dates given are two standard deviations. Age uncertainties ranged from \pm 15 to \pm 110 years

178 with a mean of \pm 40 years. Only one date has an uncertainty of \pm 110 years and the remaining 16

179 dates have uncertainties lower than \pm 70 years, across the $12 \mathrm{ka}$ record.

180 U-Th dates indicate that WE stalagmite grew over three time intervals separated by two hiatuses.

181 The stalagmite began to grow $12.2 \mathrm{ka}$ BP and stopped growing at $10.8 \mathrm{ka} \mathrm{BP}$. After an

182 interruption of over $1 \mathrm{ka}$, the stalagmite resumed growth $9.4 \mathrm{ka} \mathrm{BP}$ and stopped growing $4.3 \mathrm{ka}$

183 BP. Finally, after a $\sim 2$ ka growth interruption, the stalagmite resumed growth once again 2.6 ka

184 BP and stopped growing 300 years BP (years BP are relative to C.E. 1950). These two hiatuses

185 are visually distinctive as a shift in color, fabric and vertical growth orientation (Fig. S1 \& S4).

186 Importantly, the stalagmite spans the intervals of interest corresponding to the YD and $8.2 \mathrm{ka}$

187 cooling events and the LIA. We developed the chronology of these sections based on piecewise-

188 linear models to account for non-linearity in stalagmite growth (Fig. S3). 
192 The $\delta^{18} \mathrm{O}$ and $\delta^{13} \mathrm{C}$ data was obtained at the Paleoclimate and Stable Isotope Laboratory (PSI)

193 in the Department of Geosciences at Auburn University, Alabama. Along the main growth

194 axis, 688 calcite powder micro samples were drilled at a sampling resolution of $500 \mu \mathrm{m}$ (Table

195 S2). The carbon and oxygen isotopic composition of calcite powders were analyzed with a

196 Thermo Scientific Delta V Plus Isotope Ratio Mass Spectrometer interfaced with a

197 Thermo Gasbench II. Long-term (3-year) reproducibility for reference standard IAEA-603 is

$198 \quad 0.09 \%$ and $0.07 \%$ for $\delta^{18} \mathrm{O}$ and $\delta^{13} \mathrm{C}$, respectively. Reproducibility of $\delta^{18} \mathrm{O}$ and $\delta^{13} \mathrm{C}$ (average

199 standard deviation for each sample of the WE data-set) were $0.06 \%$ for both.

2013. Results and Discussion

202 The WE stalagmite long-term average $\delta^{18} \mathrm{O}$ composition is $-3.3 \%$, with a range from $-4.3 \%$ to -

$2032.1 \%$. The most negative isotopic values occur over the intervals $11.8-11 \mathrm{ka} \mathrm{BP}, 9.4-8 \mathrm{ka} \mathrm{BP}$ and $204 \quad 0.5-1 \mathrm{ka} \mathrm{BP}$ and the most positive over the intervals 6.5-5.5 ka BP and 10.8-11 ka BP (Fig. 2).

205 We focus this section on the climate interpretation of four separate windows of the WE

206 stalagmite $\delta^{18} \mathrm{O}$ record, which span the YD and $8.2 \mathrm{ka}$ cooling events, the Early to Mid-Holocene

207 and the Late Holocene. We provide a final discussion on the WE stalagmite $\delta^{13} \mathrm{C}$ series in

208 support of hydroclimate inferences from the $\delta^{18} \mathrm{O}$ record.

209

210 3.1. Precipitation $\delta^{18} \mathrm{O}$ variability and the amount effect

211 The amount effect is well documented within tropical to subtropical regions (Rozanski et al., 212 1993) but has not been well documented within the SE US, although modeling data with isotope 213 tracers suggest its existence in the southernmost extension of this region (Vuille et al., 2003). 
214 Relevant studies by Dhungana and Aharon (2019) and Lambert and Aharon (2010) suggested the

215 existence of an amount effect on interannual timescales by examining a couple of years of

216 rainfall isotopic data.

217 We examined a 10-year record (2005-2015) of precipitation amount and $\delta^{18} \mathrm{O}$ data produced

218 by the University of Alabama (Dhungana and Aharon, 2019; Lambert and Aharon, 2010; McKay

219 and Lambert, 2015) in order to investigate the existence of an amount effect on seasonal and

220 interannual time scales and the impact of shifts in seasonality on precipitation amount and

221 annual precipitation $\delta^{18} \mathrm{O}$ (Fig. S5 and Table S3).

222 Examination of decadal precipitation amount $(P)$ and precipitation $\delta^{18} \mathrm{O}(\delta P)$ data $(2005$ -

223 2015), reveals the existence of an interannual relationship between $\delta P$ and $\triangle P$ with a slope

$224 \delta P / \triangle P=-0.0017 \%$ per $\mathrm{mm})(\mathrm{r}=0.34)($ Fig. S5A). Removal of three "anomalous" years suggests

225 a much stronger relationship $(\delta P / \Delta P=-0.003 \%$ per $\mathrm{mm})(\mathrm{r}=0.92)($ Fig. S5B). The observed

226 relationship between precipitation $\delta^{18} \mathrm{O}$ and precipitation amount on interannual timescales is the

227 result of an amount effect observed during the summer and spring seasons (hereafter jointly

228 referred to as 'summer') combined with the distinctive depleted isotopic contribution of fall and

229 winter precipitation (hereafter referred to as 'winter'). Although instrumental observations

230 support interpretation of interannual stalagmite $\delta^{18} \mathrm{O}$ variability in terms of precipitation amount

231 change, the observed variability of the slope $\delta P / \Delta P$ (i.e. Fig. S5A versus $\mathrm{S} 5 \mathrm{~B}$ ) is significant

232 enough to introduce uncertainty in quantitative precipitation estimates determined sensu Medina-

233 Elizalde and Rohling (2012). In this study, we interpret stalagmite $\delta^{18} \mathrm{O}$ variability to reflect

234 precipitation amount qualitatively, although we examine the shift in 'winter' and 'summer'

235 precipitation amount using the instrumental data necessary to explain stalagmite $\delta^{18} \mathrm{O}$ variability. 
An observation from the instrumental record relevant to support hydroclimate interpretations of stalagmite $\delta^{18} \mathrm{O}$, is that 'winter' precipitation shows low interannual $\delta^{18} \mathrm{O}$

238 variability, the highest frequency of depleted $\delta^{18} \mathrm{O}$ values, and no amount effect on interannual

239 timescales. An amount effect on interannual timescales is particularly observed during the 240 summer and spring seasons (Fig. S6). In order to interpret WE stalagmite $\delta^{18} \mathrm{O}$ variability, we 241 examine the effect of shifting the amount of precipitation during 'summer', relative to modern 242 conditions, on the decadal average $\delta^{18} \mathrm{O}$ composition of rainfall, while maintaining 'winter' 243 precipitation amount constant, and vice versa, the effect of shifts in 'winter' precipitation on 244 rainfall $\delta^{18} \mathrm{O}$ while keeping 'summer' precipitation constant (Fig. 3 and Table S3). We explore 245 decadal rainfall isotopic shifts because this time resolution is relevant to that of the WE 246 stalagmite isotopic records (i.e. 7-44 years) (Fig. 2). This analysis provides three main observations relevant to the hydroclimate interpretation 248 of stalagmite $\delta^{18} \mathrm{O}$ : (i) a large increase in 'winter' precipitation amount does not produce per se a 249 negative annual precipitation $\delta^{18} \mathrm{O}$ shift, but only via dilution of isotopically enriched 'summer' 250 precipitation (Fig. 3). A doubling of 'winter' precipitation amount, for instance, would only shift 251 the decadal average $\delta^{18} \mathrm{O}$ composition of rainfall by $-0.24 \%$ when maintaining 'summer' 252 precipitation unchanged (Fig. 3). (ii) Peak negative decadal isotopic shifts can only be attained if 253 'summer' precipitation increases. This is the result of the amount effect observed during the 254 summer and spring seasons (Fig. S6). Doubling of 'summer' precipitation amount would shift 255 decadal average rainfall $\delta^{18} \mathrm{O}$ by $-1.4 \%$, while doubling 'winter' precipitation amount would 256 only shift it by $-0.24 \%$, as mentioned above (Fig. 3). (iii) Maximum positive decadal rainfall 257 isotopic shifts can only be attained by decreasing both 'winter' and 'summer' precipitation. 258 Decreasing 'summer' precipitation amount alone can produce a maximum positive shift of 
$\sim+0.21 \%$ when precipitation is reduced by $48 \%$. A larger 'summer' precipitation reduction starts

260 shifting rainfall $\delta^{18} \mathrm{O}$ in the opposite direction, by enhancing the influence of isotopically

261 depleted 'winter' rainfall on the annual isotopic budget. Maximum decline of 'winter'

262 precipitation to zero, produces a decadal averaged positive rainfall isotopic shift of $+0.85 \%$ (Fig.

263 3). This shift corresponds to the difference between the decadal averaged annual amount-

264 weighed $\delta^{18} \mathrm{O}$ composition of rainfall (including all seasons) versus the decadal averaged

265 'summer' amount-weighed $\delta^{18} \mathrm{O}$ composition of rainfall.

\subsection{Expected equilibrium stalagmite $\delta^{18} O$ values}

268 A necessary condition to interpret the oxygen isotopic composition of stalagmite calcite as a

269 record of precipitation $\delta^{18} \mathrm{O}$ variability is that calcite $\delta^{18} \mathrm{O}$ is precipitated under isotopic

270 equilibrium conditions. Results from calculations using empirical isotopic equilibrium equations

271 indicate calcite precipitated at or near equilibrium under the observed cave air temperature

$272\left(14.7^{\circ} \mathrm{C}\right)$ and range of annual amount-weighted $\delta^{18} \mathrm{O}$ composition of rainfall (i.e. $-5.9 \%$ to -3.9

$273 \%$ ) would have a $\delta^{18} \mathrm{O}$ composition ranging from $-6.6 \%$ to $-2.9 \%$ in agreement with the WE

274 stalagmite isotopic composition (Table S4). Supported by these results, in addition to the

275 observed cave environmental conditions (relative humidity $\sim 100 \%$ and stable temperature), we

276 suggest that stalagmite WE calcite was precipitated near isotopic equilibrium conditions and

277 likely faithfully records precipitation $\delta^{18} \mathrm{O}$ variability (Table S4). We note finally that WE

278 stalagmite does not have distinctive temporal laminations to produce a conventional Hendy Test . 279 


\subsection{Younger Dryas and $8.2 \mathrm{ka}$ cooling events}

283

Figures 4 and 5 place the WE stalagmite-precipitation $\delta^{18} \mathrm{O}$ record in the context of high-

284 latitude climate variability during the YD and $8.2 \mathrm{ka}$ cooling events. Stalagmite $\delta^{18} \mathrm{O}$ values

285 become progressively more negative during the evolution of these two events by about $\sim-1.2 \%$.

286 The observed relationship between precipitation $\delta^{18} \mathrm{O}$ and precipitation amount observed today

287 on interannual timescales suggests that such negative shift in stalagmite $\delta^{18} \mathrm{O}$ reflects persistent

288 increases in precipitation amount in the SE US during the peak of these events (Fig. S5). We

289 acknowledge that the negative stalagmite $\delta^{18} \mathrm{O}$ shift observed during the YD and 8.2 ka events

290 could reflect regional atmospheric cooling via the same-sign relationship between water

291 condensation temperature and precipitation $\delta^{18} \mathrm{O}$. Global circulation model hosing experiments

292 with isotope tracers suggest, however, that precipitation $\delta^{18} \mathrm{O}$ would have remained practically

293 unchanged in the SE US (LeGrande et al., 2006). WE cave air cooling during these events, on

294 the other hand, would have increased calcite $\delta^{18} \mathrm{O}$ not decrease it, due to thermodynamic isotopic

295 fractionation between drip water and calcite, probably counterbalancing positive rainfall isotopic

296 shifts driven by atmospheric cooling.

297 The sensitivity test we applied using the instrumental data (Fig. 3) suggests that the

298 stalagmite isotopic shift of $\sim-1.2 \%$ can be explained by a $90 \%$ increase of 'summer'

299 precipitation relative to today's conditions. As mentioned previously, an increase in 'winter'

300 precipitation by $100 \%$ would only shift rainfall $\delta^{18} \mathrm{O}$ by $-0.2 \%$ (while maintaining 'summer'

301 precipitation amount constant). We cannot discard that 'winter' precipitation declined at the

302 time, because such a large increase in the influence of 'summer' precipitation would mask the

303 isotopic signal of declining 'winter' rainfall amount. As an example, a coeval decrease of

304 'winter' precipitation amount by $100 \%$ would only shift rainfall $\delta^{18} \mathrm{O}$ by $-0.1 \%$ when 'summer' 
305 precipitation increases $90 \%$ (Table S3). We point out that a decrease of 'summer' precipitation to 306 zero while maintaining 'winter' precipitation unchanged would decrease rainfall $\delta^{18} \mathrm{O}$ only by a 307 maximum of $-0.7 \%$ and thus would fail to explain the observed stalagmite isotopic change of $3081.2 \%$. An increase in 'summer' precipitation is thus necessary to explain observations. We lastly 309 note that the suggested increase in 'summer' precipitation by $90 \%$ yields an increase in annual 310 precipitation, even when winter precipitation amount is reduced by as much as $90 \%$; in 311 agreement with inferences based on the observed amount effect on interannual timescales (Fig. 312 S6).

313 The YD and 8.2 ka events were associated with AMOC slowdown, North Atlantic 314 cooling, a southward displacement of the ITCZ, and precipitation reductions in the NH low 315 latitudes as suggested by climate model hosing experiments (Dahl et al., 2005; LeGrande et al., 316 2006; Otto-Bliesner and Brady, 2010; Vellinga and Wood, 2002) and paleoclimate records (Lea 317 et al., 2003; Peterson and Haug, 2006). A southward displacement of the ITCZ during the YD 318 and $8.2 \mathrm{ka}$ events in particular is suggested by the Cariaco Basin Ti\% sediment record from 319 offshore Venezuela and from its antiphase relationship with hydroclimate records from south 320 America (Peterson and Haug, 2006) (Figs. 4 and 5). A southward displacement of the ITCZ due 321 to AMOC slowdown is also supported by climate model simulations and expected to result from 322 atmospheric circulation changes associated with significant tropical cooling (Otto-Bliesner and 323 Brady, 2010; Stouffer et al., 2006; Vellinga and Wood, 2002).

324 Model simulations of AMOC slowdown/shutdown feature a 'cold tongue' of surface 325 temperatures that extends from the North Atlantic high-latitudes through the eastern North 326 Atlantic sector down to the tropical region (Otto-Bliesner and Brady, 2010; Vellinga and Wood, 327 2002). This ocean 'cold tongue' is flanked by mild or warmer surface temperatures in the 
western North Atlantic mid-latitude and Gulf of Mexico regions, the main sources of moisture

329 into the SE US region (Gimeno et al., 2012; Li et al., 2013). Additional model hosing

330 experiments that address shifts in seasonality (LeGrande et al., 2006; Renssen et al., 2002),

331 suggest that AMOC slowdown decreases winter surface temperatures while summer

332 temperatures remain unchanged or increase in the Gulf of Mexico and SE US. Warmer ocean

333 conditions in the Gulf of Mexico and western North Atlantic, particularly in the summer, coeval

334 with stronger meridional and zonal temperature gradients in the North Atlantic would be

335 conducive to increasing local precipitation in the SE US. Enhanced precipitation in the SE US is

336 actually supported by various model experiments of freshwater perturbation to AMOC that at the

337 same time simulate coeval precipitation reduction in the tropical Atlantic (LeGrande et al., 2006;

338 Renssen et al., 2002; Vellinga and Wood, 2002), in agreement with observations (Fig. 4 and 5).

339 We acknowledge that these observations have potential implications for the inferred position and

340 strength of the North Atlantic subtropical high pressure system during these climate events that

341 deserve a deeper exploration beyond the scope of this study.

342 The results from this study suggesting the SE US was wet when the North Atlantic was

343 cold and the tropics experienced negative precipitation anomalies agree with independent

344 paleoclimate evidence based on pollen and plant macrofossil records from Lake Tulane, Florida.

345 These records spanning the last 60 ka suggest that Florida was wet and warm during Heinrich

346 events, including the YD, and during the stadial intervals of Dansgaard-Oeschger events (Grimm

347 et al., 2006). Grimm et al., (2006) suggest that a reduction in North Atlantic deep water

348 formation decreased the northward ocean heat transport and retained warmth in the subtropical

349 Atlantic and Gulf of Mexico, essentially producing a polar-subtropical seesaw. Paleoclimate

350 evidence both supporting and opposing the seesaw pattern exists from the Caribbean, as 
351 described in detail by Grimm et al. (2006). Regardless of the mechanism ultimately enhancing

352 summer precipitation in the SE US, model simulations and paleoclimate records provide

353 evidence of an antiphase climate relationship between the SE US and the eastern subtropical

354 North Atlantic and southern Caribbean, during events of AMOC slowdown/shutdown. We note

355 that the instrumental record indicates an antiphase relationship between precipitation in the SE

356 US and the broader Caribbean on interannual timescales (Fig. 1) and during the summer season 357 (Fig. S7).

\subsection{Early to Mid-Holocene Climate Variability}

360 The WE stalagmite suggests a long-term $+1 \%$ isotopic shift occurring from $\sim 7.5$ ka to $\sim 5.5$

361 ka (Fig. 6). A decline in 'summer' precipitation alone would not explain this large positive

362 isotopic shift, because it would increase $\delta^{18} \mathrm{O}$ by $+0.2 \%$ maximum, when precipitation amount

363 decreases by 49\% (Fig. 3). As mentioned previously, a decrease of 'summer' precipitation

364 amount beyond this level would no longer increase annual precipitation $\delta^{18} \mathrm{O}$ because the

365 depleted isotopic composition of 'winter' rainfall becomes dominant after this threshold (Fig. 3).

366 An additional 75\% decline of 'winter' precipitation amount would be needed to explain the Mid-

367 Holocene stalagmite positive isotopic shift. We note that 'summer' precipitation must have

368 declined together with 'winter' precipitation, because the maximum isotopic shift when 'winter'

369 precipitation becomes zero is $0.8 \%$, therefore it would still be insufficient to explain the mid-

370 Holocene stalagmite shift (Fig. 3). The precipitation decline from $\sim 7$ to $\sim 6$ ka suggested by the

371 WE stalagmite is consistent with pollen records from wetlands in the SE US that suggest a

372 decline over this time of high-diversity taxa indicative of moist soils (Goman and Leigh, 2004).

373 In addition, a hydroclimate transition from wet to dry conditions at the time is also suggested by 
374 a decrease in the abundance of Pinus inferred from pollen records from lake Tulane, Florida

375 (Grimm et al., 1993; Grimm et al., 2006).

376 Inferred climate evolution from the Early Holocene (9-7 ka BP) to the mid-Holocene (6-5 ka

377 BP) in the SE US coincides with boreal summer insolation reduction, North Atlantic cooling

378 (Marcott et al., 2013; Renssen et al., 2005; Wanner et al., 2011), decrease rainfall in the

379 Caribbean (Haug et al., 2001) and weakening of Northern Hemisphere monsoon intensity

380 (Fleitmann et al., 2007) (Fig. 6). Evidence of mid-Holocene precipitation reduction is also

381 provided by paleoclimate records from Cuba (Fensterer et al., 2013), and from the central and

382 northwestern US (Shin et al., 2006). Lastly, Early Holocene precipitation maxima in the SE US

383 coeval with Northern Hemisphere warm conditions is consistent with projected hydroclimate

384 change in the region by the end of this century resulting from anthropogenic warming (Collins et 385 al., 2013).

386 The drying trend suggested by the WE stalagmite is interrupted by two climate reversals

387 between 6 and 4.5 ka BP indicated by prominent negative isotopic excursions (Fig. 2 and Fig.

388 S8). These inferred climate reversals are also represented, although more subtlety, by the

389 stalagmite $\delta^{18} \mathrm{O}$ record from DeSoto Caverns, Alabama, that spans the interval between $\sim 6 \mathrm{ka}$

390 and 1 ka BP (Aharon and Dhungana, 2017) (Fig. S8). Similar but more subtle hydroclimate

391 cycles are shown by paleoclimate records from the Caribbean which are coeval with North

392 Atlantic temperature variability (Haug et al., 2001; Marcott et al., 2013)(Fig. 5). Isotopic

393 reversals are observed in the WE stalagmite $\delta^{13} \mathrm{C}$ record, also suggesting a local hydrological

394 change at the time (Fig. 2). We propose that the speleothem isotopic records from Alabama

395 probably record an amplified regional hydrological response to North Atlantic climate conditions

396 perhaps reflecting that dynamical processes became progressively less influential in controlling 
moisture sources into the SE US from the early to the mid-Holocene. During this time, the region

398 began to experience an increase in precipitation recycling from precipitation of terrestrial origin

399 (Dominguez et al., 2006) that became more important as oceanic sources of moisture became

400 less dominant as the North Atlantic cooled (Gimeno et al., 2012; Li et al., 2013).

\subsection{Late-Holocene Climate Variability}

During the transition from the Medieval Climate Anomaly time interval to the Little Ice

404 Age (Mann et al., 2009), WE stalagmite $\delta^{18} \mathrm{O}$ shows a negative isotopic shift from 1.2 to $0.4 \mathrm{ka}$

405 BP of $\sim-0.8 \%$ (Fig. 7). The stalagmite negative isotopic excursion coincides with the LIA

406 interval (Mann et al., 2009); arguably the Holocene's coldest period in the North Atlantic

407 (Marcott et al., 2013) and the driest in the Caribbean (Higuera-Gundy et al., 1999; Hodell et al.,

408 1991; Peterson and Haug, 2006). Similar to our interpretation concerning the YD and $8.2 \mathrm{ka}$

409 events, we suggest this negative isotopic excursion reflects an increase in 'summer' precipitation.

410 Tree ring records from the eastern SE US spanning the last 1000 years (Stahle and Cleaveland,

411 1992) do not suggest a long-term shift in spring precipitation during the LIA interval. Thus, the

412 long-term stalagmite isotopic shift associated with the LIA is likely to reflect mostly summer

413 precipitation changes during this time. Climate variability in the SE US across the YD, 8.2 ka,

414 and LIA events support a connection with AMOC shifts (Keigwin and Boyle, 2000; Lund et al.,

415 2006); in the case of the LIA, perhaps reflecting ocean-atmospheric feedbacks to forcing from

416 volcanic sulfur emissions and total solar irradiance at the time (Andres and Peltier, 2016; Free

417 and Robock, 1999). 


\subsection{Stalagmite Carbon Isotopes}

421 Across the full length of the WE stalagmite, and during the prominent climate events

422 highlighted above, the stalagmite $\delta^{13} \mathrm{C}$ record mimics the oxygen isotope record (Fig. 2). The

423 carbon isotope response across these events suggests hydrological shifts affecting vegetation

424 type, density, and/or soil microbial productivity. We note that most of the stalagmite $\delta^{13} \mathrm{C}$ record

425 have values that suggest a strong dominance of carbon of bedrock origin with positive isotopic

426 compositions and only minor contributions of carbon from vegetation dominated by C4 plants

427 (Fairchild and Baker, 2012). We therefore conclude that stalagmite calcite covariance between

$428 \delta^{18} \mathrm{O}$ and $\delta^{13} \mathrm{C}$ probably reflects shifts in karst hydrology whereby wetter conditions would favor

429 faster infiltration, decreased $\mathrm{pCO}_{2}$ degassing and reduced prior calcite precipitation, ultimately

430 producing lower $\delta^{13} \mathrm{C}$ values from a bedrock-dominated carbon baseline (Fairchild and Baker,

431 2012).

432

433 4. Conclusion

434 We produced high-resolution stalagmite $\delta^{18} \mathrm{O}$ and $\delta^{13} \mathrm{C}$ records of hydroclimate from

435 Alabama spanning the last $12 \mathrm{ka}$, extending the existing regional paleoclimate record to the early

436 Holocene. Hydroclimate in Alabama is linked to the broader Southeastern United States (SE US)

437 as suggested by spatial correlation analysis using the instrumental record of precipitation

438 amount. We interpret the stalagmite isotope records to reflect: (i) an amount effect observed on

439 interannual timescales, and; (ii) shifts in the relative contribution of changes in spring-summer

440 versus fall-winter rainfall amount. We find a close connection between hydroclimate variability

441 in the SE US, North Atlantic high latitude climate variability and Caribbean/Gulf of Mexico

442 hydroclimate. A consistent picture emerges whereby spring-summer precipitation in the SE US 
443 increases during events of high latitude cooling associated with Atlantic Meridional Circulation

444 slowdown/shutdown, such as during the Younger Dryas, $8.2 \mathrm{ka}$ and Little Ice Age cooling

445 events. Speleothem evidence of hydroclimate change is supported by pollen records from Florida

446 and shows consistency with climate model studies of AMOC slowdown/shutdown. WE

447 speleothem isotopic records suggest that annual precipitation decreased in the SE US across the

448 climate transition from the early Holocene ('Holocene Climate Optimum') to the late Holocene

449 (the 'Neoglacial') in the Northern Hemisphere, generally attributed to external orbital forcing.

450 Results from this study have implications for our understanding of the sensitivity of subtropical

451 North Atlantic hydroclimate to abrupt melting of the Greenland ice sheet and its influence on

452 AMOC in a future dominated by increasing greenhouse gases.

454 Acknowledgments

455 We are specially thankful to Mr. Milton Polsky, War Eagle cave land owner, for allowing us to 456 access the cave and for his support during fieldwork. We offer special thanks also to Dr. Rajesh

457 Dhungana for providing the rainfall isotopic data collected at the University of Alabama by Katie 458 McKay and Dr. Joe Lambert. We thank Dr. Joe Lambert and Prof. Raymond Bradley for 459 providing valuable comments that helped improve this manuscript. Support to this project came 460 from Prof. Medina's startup funding from Auburn University.

\section{Figure Captions}

463 Figure 1. Spatio-temporal correlation analysis of precipitation (monthly values from 1901 to 4642013 and with a spatial coverage of $0.5^{\circ}$ latitude by $0.5^{\circ}$ longitude) at the location $\left(34^{\circ} 31^{\prime} \mathrm{N}\right.$, $\left.46586^{\circ} 11^{\prime} \mathrm{W}\right)$ (War Eagle Cave, Alabama). Location of War Eagle Cave indicated with light blue 466 star. The precipitation data set comes from the GPCC Global Precipitation Climatology Centre 
467 and is available from https://psl.noaa.gov/data/gridded/data.gpcc.html. The map was created

468 using the R software .

469

470 Figure 2. Stalagmite War Eagle (WE) $\delta^{18} \mathrm{O}$ and $\delta^{13} \mathrm{C}$ records spanning the last $12.2 \mathrm{ka}$. Vertical

471 colored bars indicate relevant time intervals discussed in the manuscript. The time resolution of

472 these records is from 7 to 44 years, decreasing as time progresses from the Early to the Late

473 Holocene.

474

475 Figure 3. Plot illustrating the change in the decadal average $\delta^{18} \mathrm{O}$ composition of rainfall

476 resulting from shifting the amount of precipitation during spring and summer labelled as

477 'summer', and fall and winter, labeled as 'winter', relative to modern conditions. The $\mathrm{X}$ axis

478 represents the fractional change in precipitation amount from modern conditions; $1=100 \%$

479 increase or a doubling of precipitation amount, and $-1=100 \%$ decline in precipitation amount.

480 Blue line represents the expected decadal average $\delta^{18} \mathrm{O}$ composition shift from changing the

481 amount of precipitation during 'winter' from $-100 \%$ (no precipitation) to plus $100 \%$ (doubling)

482 while keeping 'summer' precipitation amount constant. Dark orange line, represents the

483 expected decadal average $\delta^{18} \mathrm{O}$ composition shift from changing the amount of precipitation

484 during 'summer' keeping 'winter' precipitation amount constant. These calculations include the

485 amount effect relationship during the summer and spring seasons observed today.

486 A decrease in 'summer' precipitation increases the decadal average $\delta^{18} \mathrm{O}$ composition of rainfall,

487 because of the inverse relationship between precipitation amount and precipitation $\delta^{18} \mathrm{O}$ during

488 the summer and spring, up to the point when the decline of 'summer' precipitation amount and

489 its relatively positive isotopic composition "enhances" the influence of the depleted isotopic 
composition that characterizes 'winter' precipitation (shown in plot section as " 'winter' isotopic

491 composition dominates"). The maximum positive isotopic shift produced from a reduction in

492 'summer' precipitation amount per se, keeping 'winter' precipitation constant, is $0.21 \%$ o

493 associated with a $40 \%$ precipitation amount reduction. A larger decrease in 'summer'

494 precipitation amount no longer increases the isotopic composition of rainfall, because as

495 mentioned above the depleted isotopic composition of winter begins to dominate. On the other

496 hand, because there is no relationship between precipitation amount and precipitation $\delta^{18} \mathrm{O}$

497 during 'winter' and there is an amount effect during summer, an increase in 'winter'

498 precipitation has a much modest effect that an increase in 'summer' precipitation amount on

499 rainfall $\delta^{18} \mathrm{O}$. A doubling in the amount of 'winter' precipitation is expected to decrease the

500 decadal average $\delta^{18} \mathrm{O}$ composition of rainfall by $0.24 \%$, whereas a doubling in 'summer'

501 precipitation amount would decrease the $\delta^{18} \mathrm{O}$ of rainfall by $1.4 \%$.

502

503 Figure 4. Blow up comparing the NGRIP ice core $\delta^{18} \mathrm{O}$ record (panel A) (Rasmussen et al.,

504 2006), the Ti\% record from the Cariaco Basin, offshore Venezuela (panel B) (Haug et al., 2001)

505 and the WE stalagmite $\delta^{18} \mathrm{O}$ record (panel $\mathrm{C}$, this study) over the Younger Dryas time interval.

506 Note that top $\mathrm{X}$-axis representing panels A and B and the bottom X-axis representing panel C,

507 are shifted relative to each other with a maximum offset of $\sim 200 \mathrm{yrs}$, in order to accommodate a

508 dating uncertainty in the layer counting of young ice of $\pm 120 \mathrm{yrs}$ in the NGRIP ice core record

509 (Rasmussen et al., 2006) and in the stalagmite $\delta^{18} \mathrm{O}$ record $\sim 12 \mathrm{ka}$ BP of \pm 70 yrs (Table S1).

510 Top X-scale corresponds to that of the records presented on panels A and B and the bottom X-

511 scale corresponds to the WE stalagmite record. 
513 Figure 5. Blow up comparing the NGRIP ice core $\delta^{18} \mathrm{O}$ record (panel A) (Rasmussen et al.,

514 2006), the Ti\% record from the Cariaco Basin, offshore Venezuela (panel B) and the WE

515 stalagmite $\delta^{18} \mathrm{O}$ record (panel C, this study) over the $8.2 \mathrm{ka}$ cooling event.

516

517 Figure 6. Blow up comparing a North Atlantic sea surface temperature reconstruction (panel A)

518 (Marcott et al., 2013), the Cariaco Basin Ti\% record (panel B) (Haug et al., 2001) and the WE

519 stalagmite $\delta^{18} \mathrm{O}$ record (panel C, this study) spanning the transition from the Early to the Mid-

520 Holocene. Darker continuous lines represent 7-point moving averages.

522 Figure 7. Blow up comparing a Northern Hemisphere surface temperature record (panel

524 stalagmite $\delta^{18} \mathrm{O}$ record (panel $\mathrm{C}$, this study) spanning the late Holocene. The mean resolution of

525 the stalagmite record over this time interval is 44 yrs.

526

References

1. Aharon, P., and Dhungana, R., 2017, Ocean-atmosphere interactions as drivers of mid-tolate Holocene rapid climate changes: Evidence from high-resolution stalagmite records at DeSoto Caverns, Southeast USA: Quaternary Science Reviews, v. 170, p. 69-81.

2. Anandhi, A., and Bentley, C., 2018, Predicted 21 st century climate variability in southeastern U.S. using downscaled CMIP5 and meta-analysis: CATENA, v. 170, p. 409420.

3. Andres, H. J., and Peltier, W. R., 2016, Regional Influences of Natural External Forcings on the Transition from the Medieval Climate Anomaly to the Little Ice Age: Journal of Climate, v. 29, no. 16, p. 5779-5800.

4. Baigorria, G. A., Jones, J. W., and O'Brien, J. J., 2007, Understanding rainfall spatial variability in southeast USA at different timescales: International Journal of Climatology, v. 27, no. 6, p. 749-760.

5. Bard, E., Rostek, F., Turon, J.-L., and Gendreau, S., 2000, Hydrological impact of Heinrich events in the subtropical northeast Atlantic: Science v. 289, p. 1321-1324. 
6. Broecker, W. S., Kennett, J. P., Flower, B. P., Teller, J. T., Trumbore, S., Bonani, G., and Wolfli, W., 1989, Routing of meltwater from the Laurentide Ice Sheet during the Younger Dryas cold episode: Nature, v. 341, no. 6240, p. 318-321.

7. Cheng, H., Edwards, R. L., Shen, C.-C., Polyak, V. J., Asmerom, Y., Woodhead, J., Hellstrom, J., Wang, Y., J., , Kong, X. G., Spötl, C., Wang, X. F., and Alexander, E. C., 2013, Improvements in 230Th dating, 230Th and 234U half-life values, and U-Th isotopic measurements by multi-collector inductively coupled plasma mass spectrometry.: Earth and Planetary Science Letters, v. 372, p. 82-91.

8. Collins, M., R. Knutti, R., Arblaster, J., Dufresne, J.-L., Fichefet, T., Friedlingstein, P., and Gao, X., 2013, Long-term Climate Change: Projections, Commitments and Irreversibility: Climate Change 2013: The Physical Science Basis. Contribution of Working Group I to the Fifth Assessment Report of the Intergovernmental Panel on Climate Change

9. Collins, M., Sutherland, M., Bouwer, L., Cheong, S.-M., Frölicher, T., Jacot Des Combes, H., and M. Koll Roxy, I. L., K. McInnes, B. Ratter, E. Rivera-Arriaga, R.D. Susanto, D. Swingedouw, and L. Tibig, 2019, Extremes, Abrupt Changes and Managing Risk: IPCC Special Report on the Ocean and Cryosphere in a Changing Climate.

10. Dahl, K. A., Broccoli, A. J., and Stouffer, R. J., 2005, Assessing the role of North Atlantic freshwater forcing in millennial scale climate variability: a tropical Atlantic perspective: Climate Dynamics, v. 24, no. 4, p. 325-346.

11. Dhungana, R., and Aharon, P., 2019, Stable isotopes and trace elements of drip waters at DeSoto Caverns during rainfall-contrasting years: Chemical Geology, v. 504, p. 96-104.

12. Dominguez, F., Kumar, P., Liang, X.-Z., and Ting, M., 2006, Impact of Atmospheric Moisture Storage on Precipitation Recycling: Journal of Climate, v. 19, no. 8, p. 15131530 .

13. Edwards, L. R., Chen, J. H., and Wasserburg, G. J., 1987, 238U234U230Th232Th systematics and the precise measurement of time over the past 500,000 years: Earth and Planetary Science Letters, v. 81, no. 2, p. 175-192.

14. Fairchild, J., and Baker, A., 2012, Speleothem Science: from Process to Past Environments, Oxford, Wiley-Blackwell.

15. Fensterer, C., Scholz, D., Hoffmann, D. L., Spotl, C., Schroder-Ritzrau, A., Horn, C., Pajon, J. M., and Mangini, A., 2013, Millennial-scale climate variability during the last 12.5 ka recorded in a Caribbean speleothem: Earth and Planetary Science Letters, v. 361, p. 143-151.

16. Fleitmann, D., Burns, S., Mangini, A., Mudelsee, M., Kramers, J., Villa, I., Neff, U., AlSubbary, A., Buettner, A., Hippler, D., and Matter, A., 2007, Holocene ITCZ and Indian Monsoon Dynamics Recorded in Stalagmites from Oman and Yemen (Socotra): Quaternary Science Reviews, v. 26, p. 170-188.

17. Free, M., and Robock, A., 1999, Global warming in the context of the Little Ice Age: Journal of Geophysical Research: Atmospheres, v. 104, no. D16, p. 19057-19070.

18. Gimeno, L., Stohl, A., Trigo, R. M., Dominguez, F., Yoshimura, K., Yu, L., Drumond, A., Durán-Quesada, A. M., and Nieto, R., 2012, Oceanic and terrestrial sources of continental precipitation: Reviews of Geophysics, v. 50, no. 4.

19. Goman, M., and Leigh, D., 2004, Wet early to middle Holocene conditions on the Upper Coastal Plain of North Carolina, USA: Quaternary Research, v. 61, p. 256-264. 
20. Grimm, E. C., Jacobson, G. L., Watts, W. A., Barbara, C. S. H., and Maasch, K. A., 1993, A 50,000-Year Record of Climate Oscillations from Florida and Its Temporal Correlation with the Heinrich Events: Science, v. 261, no. 5118, p. 198-200.

21. Grimm, E. C., Watts, W. A., Jacobson, G. L., Hansen, B. C. S., Almquist, H. R., and Dieffenbacher-Krall, A. C., 2006, Evidence for warm wet Heinrich events in Florida: Quaternary Science Reviews, v. 25, no. 17, p. 2197-2211.

22. Haug, G. H., Hughen, K. A., Sigman, D. M., Peterson, L. C., and Röhl, U., 2001, Southward Migration of the Intertropical Convergence Zone Through the Holocene: Science, v. 293, no. 5533, p. 1304-1308.

23. Higuera-Gundy, A., Brenner, M., Hodell, D. A., Curtis, J. H., Leyden, B. W., and Binford, M. W., 1999, A 10,300 C-14 yr record of climate and vegetation change from Haiti: Quaternary Research, v. 52, no. 2, p. 159-170.

24. Hodell, D. A., Curtis, J. H., Jones, G. A., Higuera-Gundy, A., Brenner, M., Binford, M. W., and Dorsey, K. T., 1991, Reconstruction of Caribbean climate change over the past 10,500 years: Nature, v. 352, no. 6338, p. 790-793.

25. IPBES, 2019, Summary for policymakers of the global assessment report on biodiversity and ecosystem services of the Intergovernmental Science-Policy Platform on Biodiversity and Ecosystem Services.: IPBES secretariat, Bonn, Germany.

26. Ipcc, 2014, Climate Change 2014: Impacts, Adaptation, and Vulnerability. Part A: Global and Sectoral Aspects. Contribution of Working Group II to the Fifth Assessment Report of the Intergovernmental Panel on Climate Change [Field, C.B., V.R. Barros, D.J. Dokken, K.J. Mach, M.D. Mastrandrea, T.E. Bilir, M. Chatterjee, K.L. Ebi, Y.O. Estrada, R.C. Genova, B. Girma, E.S. Kissel, A.N. Levy, S. MacCracken, P.R. Mastrandrea, and L.L. White (eds.)], Cambridge, United Kingdom and New York, NY, USA, Cambridge University Press, 1132 p.:

27. Karmalkar, A. V., Bradley, R. S., and Diaz, H. F., 2011, Climate change in Central America and México: regional climate model validation and climate change projections: Climate Dynamics, v. 37, p. 605-629.

28. Keigwin, L. D., and Boyle, E. A., 2000, Detecting Holocene changes in thermohaline circulation: Proceedings of the National Academy of Sciences, v. 97, no. 4, p. 1343-1346.

29. Keim, B., 1996, Spatial, synoptic, and seasonal patterns of heavy rainfall in the Southeastern United States: Physical Geography, v. 17, p. 313-328.

30. Lambert, J. W., and Aharon, P., 2010, Oxygen and hydrogen isotopes of rainfall and dripwater at SeSoto Caverns (Alabama, USA); Key to understanding past variability of moisture transport from the Gulf of Mexico: Geochimica Et Cosmochimica Acta, v. 74, no. 3, p. 846-861.

31. Lases-Hernández, F., Medina-Elizalde, M., Burns, S., Bernal-Uruchurtu, J. P., and Beddows, P., 2019, Monitoring Rio Secreto Cave System in the Yucatan Peninsula to Calibrate Paleoclimatic Proxies: Geochimica Et Cosmochimica Acta, v. 246, p. 41-59.

32. Lea, D. W., Pak, D. K., Peterson, L. C., and Hughen, K. A., 2003, Synchroneity of Tropical and High-Latitude Atlantic Temperatures over the Last Glacial Termination: Science, v. 301, no. 5638, p. 1361-1364.

33. LeGrande, A. N., Schmidt, G. A., Shindell, D. T., Field, C. V., Miller, R. L., Koch, D. M., Faluvegi, G., and Hoffmann, G., 2006, Consistent simulations of multiple proxy responses to an abrupt climate change event: Proceedings of the National Academy of Sciences of the United States of America, v. 103, no. 4, p. 837-842. 
34. Li, L., Li, W., and Barros, A. P., 2013, Atmospheric moisture budget and its regulation of the summer precipitation variability over the Southeastern United States: Climate Dynamics, v. 41, no. 3, p. 613-631.

35. Lund, D. C., Lynch-Stieglitz, J., and Curry, W. B., 2006, Gulf Stream density structure and transport during the past millennium: Nature, v. 444, no. 7119, p. 601-604.

36. Mann, M. E., Zhang, Z., Rutherford, S., Bradley, R. S., Hughes, M. K., Shindell, D., Ammann, C., Fluvegi, G., and Ni, F., 2009, Global Signatures and Dynamical Origins of the Little Ice Age and Medieval Climate Anomaly: Science, v. 326, p. 1256-1260.

37. Marcott, S. A., Shakun, J. D., Clark, P. U., and Mix, A. C., 2013, A Reconstruction of Regional and Global Temperature for the Past 11,300 Years: Science, v. 339, no. 6124, p. 1198-1201.

38. Matthes, F., 1939, Report of Committee on Glaciers: Trans. Am. Geophys. Union, v. 20, p. $518-535$.

39. McKay, K., and Lambert, W. J., 2015, Utilizing present-say stable water isotopes to improve paleoclimate records from the Southeast (USA), American Geophysical Union: San Francisco, CA

40. Medina-Elizalde, M., Burns, S. J., Polanco-Martinez, J., Lases-Hernández, F., Bradley, R., Wang, H.-C., and Shen, C.-C., 2017, Synchronous precipitation reduction in the American Tropics associated with Heinrich 2: Scientific Reports, v. 7, no. 1, p. 11216.

41. Otto-Bliesner, B. L., and Brady, E. C., 2010, The sensitivity of the climate response to the magnitude and location of freshwater forcing: last glacial maximum experiments: Quaternary Science Reviews, v. 29, p. 56-73.

42. Peterson, L. C., and Haug, G. H., 2006, Variability in the mean latitude of the Atlantic Intertropical Convergence Zone as recorded by riverine input of sediments to the Cariaco Basin (Venezuela): Palaeogeography Palaeoclimatology Palaeoecology, v. 234, no. 1, p. 97-113.

43. Pollock, A. L., van Beynen, P. E., DeLong, K. L., Polyak, V., and Asmerom, Y., 2016, A speleothem-based mid-Holocene precipitation reconstruction for West-Central Florida: The Holocene, v. 27, no. 7, p. 987-996.

44. Rasmussen, S. O., Andersen, K. K., Svensson, A. M., Steffensen, J. P., Vinther, B. M., Clausen, H. B., Siggaard-Andersen, M.-L., Johnsen, S. J., Larsen, L. B., Dahl-Jensen, D., Bigler, M., Röthlisberger, R., Fischer, H., Goto-Azuma, K., Hansson, M. E., and Ruth, U., 2006, A new Greenland ice core chronology for the last glacial termination: Journal of Geophysical Research: Atmospheres, v. 111, no. D6.

45. Renssen, H., Goosse, H., and Fichefet, T., 2002, Modeling the effect of freshwater pulses on the early Holocene climate: The influence of high-frequency climate variability: Paleoceanography, v. 17, no. 2, p. 10-11-10-16.

46. Renssen, H., Goosse, H., Fichefet, T., Brovkin, V., Driesschaert, E., and Wolk, F., 2005, Simulating the Holocene climate evolution at high latitudes using a coupled atmospheresea ice-ocean-vegetation model: Climate Dynamics, v. 24, p. 23-43.

47. Rozanski, K., Araguás-Araguás, L., and Gonfiantini, R., Isotopic patterns in modern global precipitation in Proceedings Climate Change in Continental Isotopic Records, American Geophisical Union, 1993, Volume 78, Geophysical Monograph

48. Shin, S.-I., Sardeshmukh, P., Webb, R., Oglesby, R., and Barsugli, J., 2006, Understanding the Mid-Holocene Climate: Journal of Climate v. 19. 
49. Stahle, D. W., and Cleaveland, M. K., 1992, Reconstruction and Analysis of Spring Rainfall over the Southeastern U.S. for the Past 1000 Years: Bulletin of the American Meteorological Society, v. 73, no. 12, p. 1947-1961.

50. Stouffer, R. J., Yin, J., Gregory, J. M., Dixon, K. W., Spelman, M., J., Hurlin, W., Weaver, A. J., Eby, M., Flato, G. M., Hasumi, H., Hu, A., Jungclaus, J. H., Kamenkovich, I. V., Levermann, A., Montoya, M., Murakami, S., Nawrath, S., Oka, A., and Peltier, W., 2006, Investigating the Causes of the Response of the Thermohaline Circulation to Past and Future Climate Changes: Journal of Climate: v. 19, p. 1365-1387.

51. Thomas, E. R., Wolff, E. W., Mulvaney, R., Steffensen, J. P., Johnsen, S. J., Arrowsmith, C., White, J. W. C., Vaughn, B., and Popp, T., 2007, The 8.2ka event from Greenland ice cores: Quaternary Science Reviews, v. 26, no. 1, p. 70-81.

52. Vellinga, M., and Wood, R. A., 2002, Global Climatic Impacts of a Collapse of the Atlantic Thermohaline Circulation: Climatic Change, v. 54, no. 3, p. 251-267.

53. Wanner, H., Solomina, O., Grosjean, M., Ritz, S. P., and Jetel, M., 2011, Structure and origin of Holocene cold events: Quaternary Science Reviews, v. 30, no. 21, p. 3109-3123. 


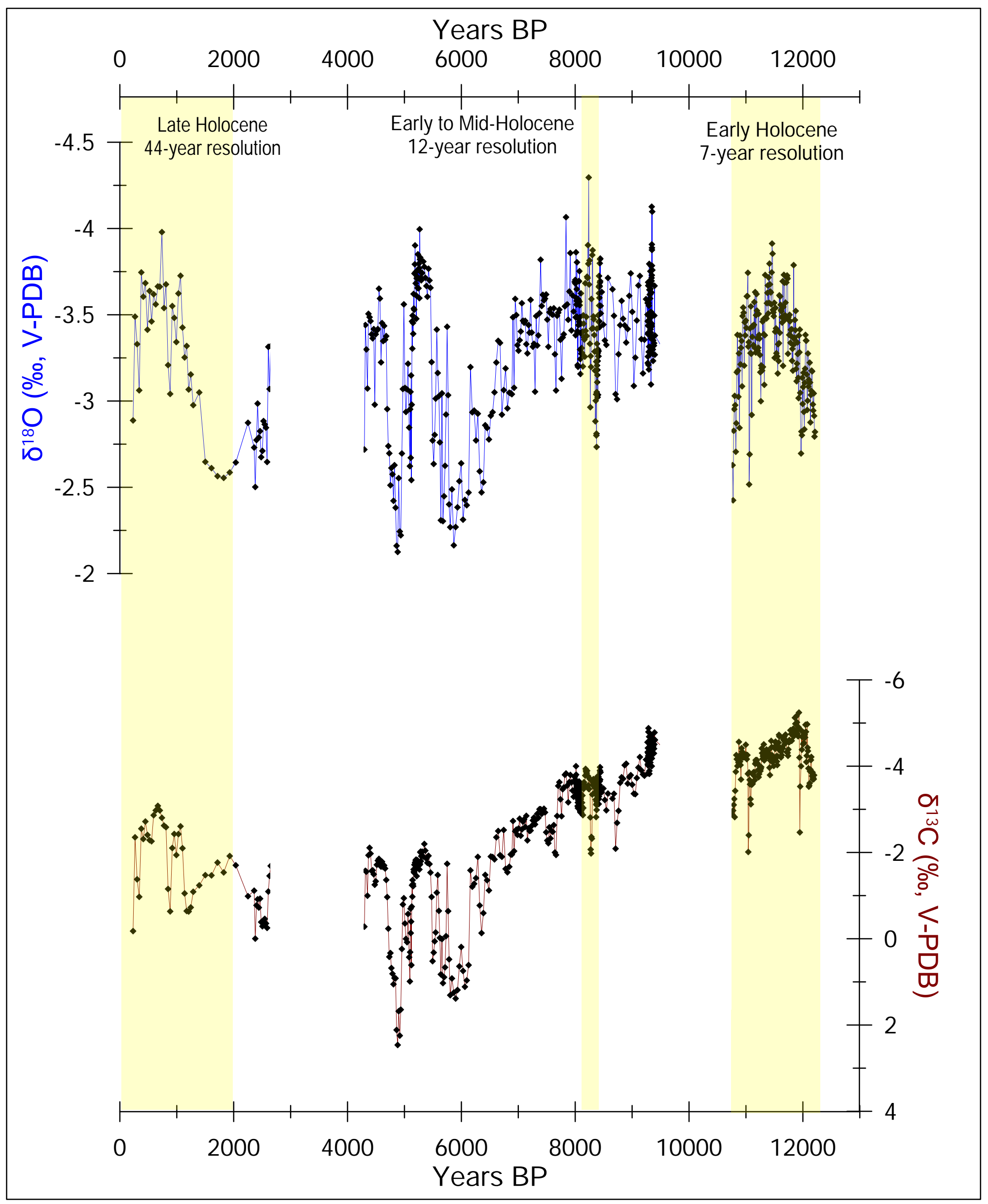

Figure 2 


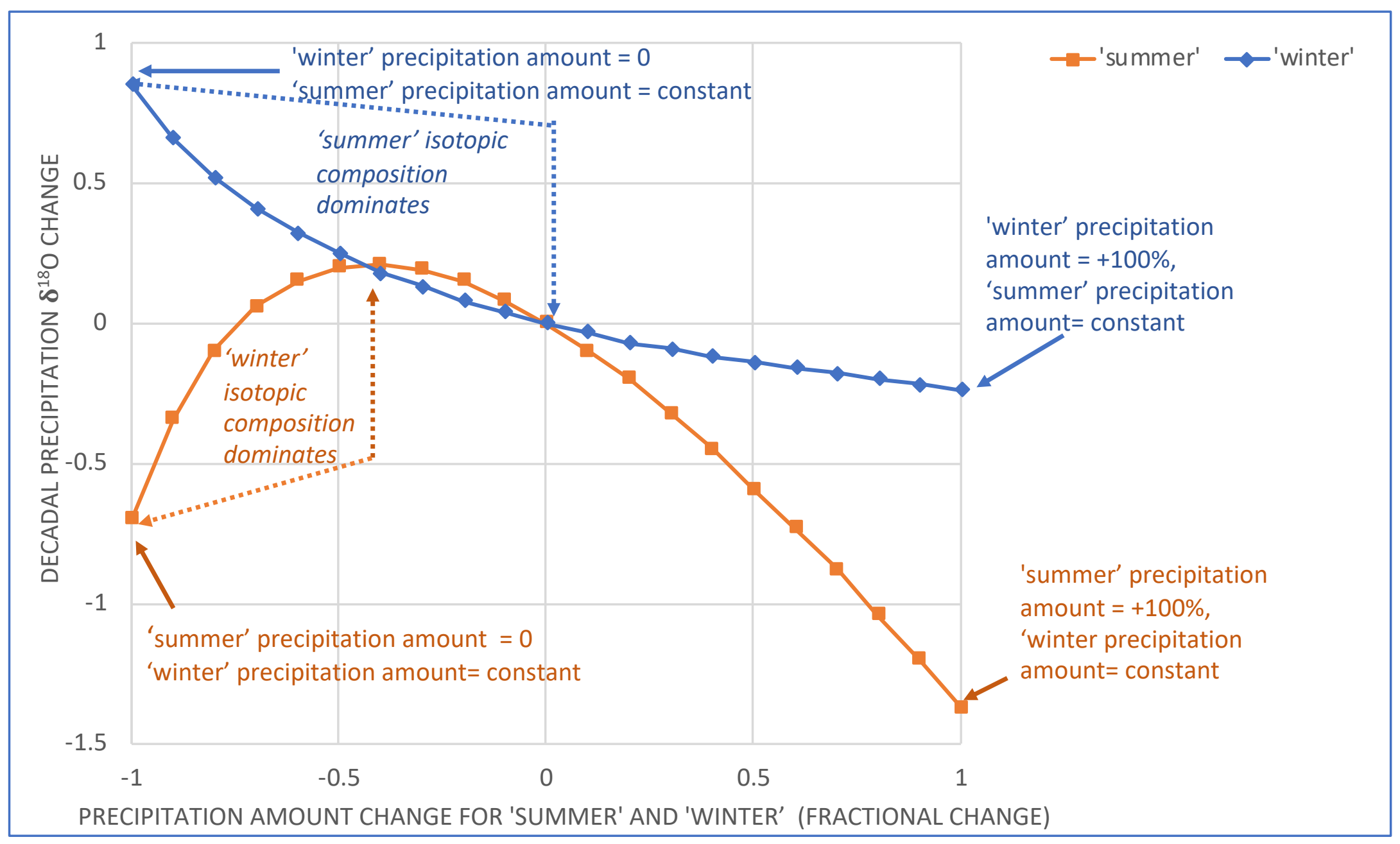

Figure 3 


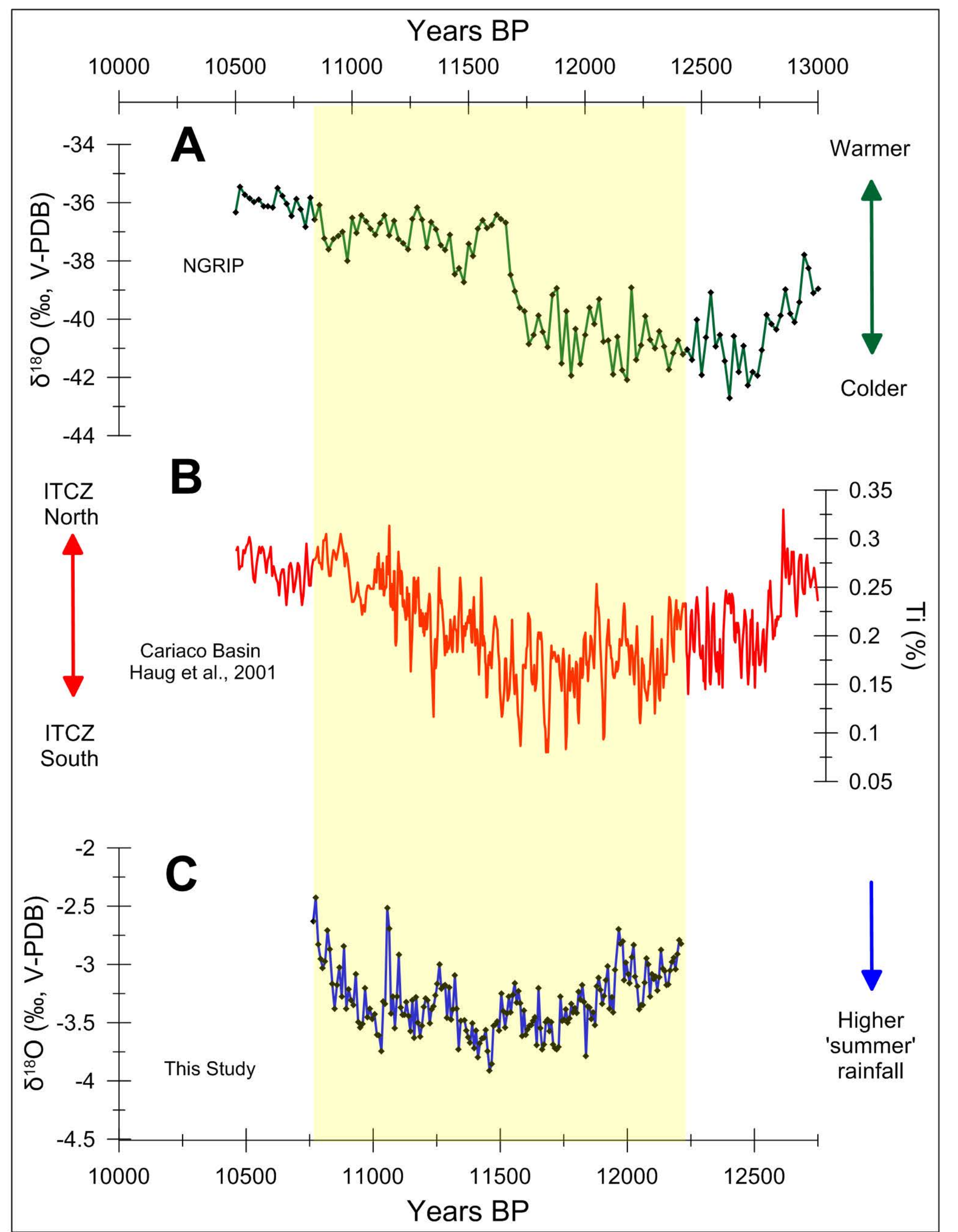

Figure 4 


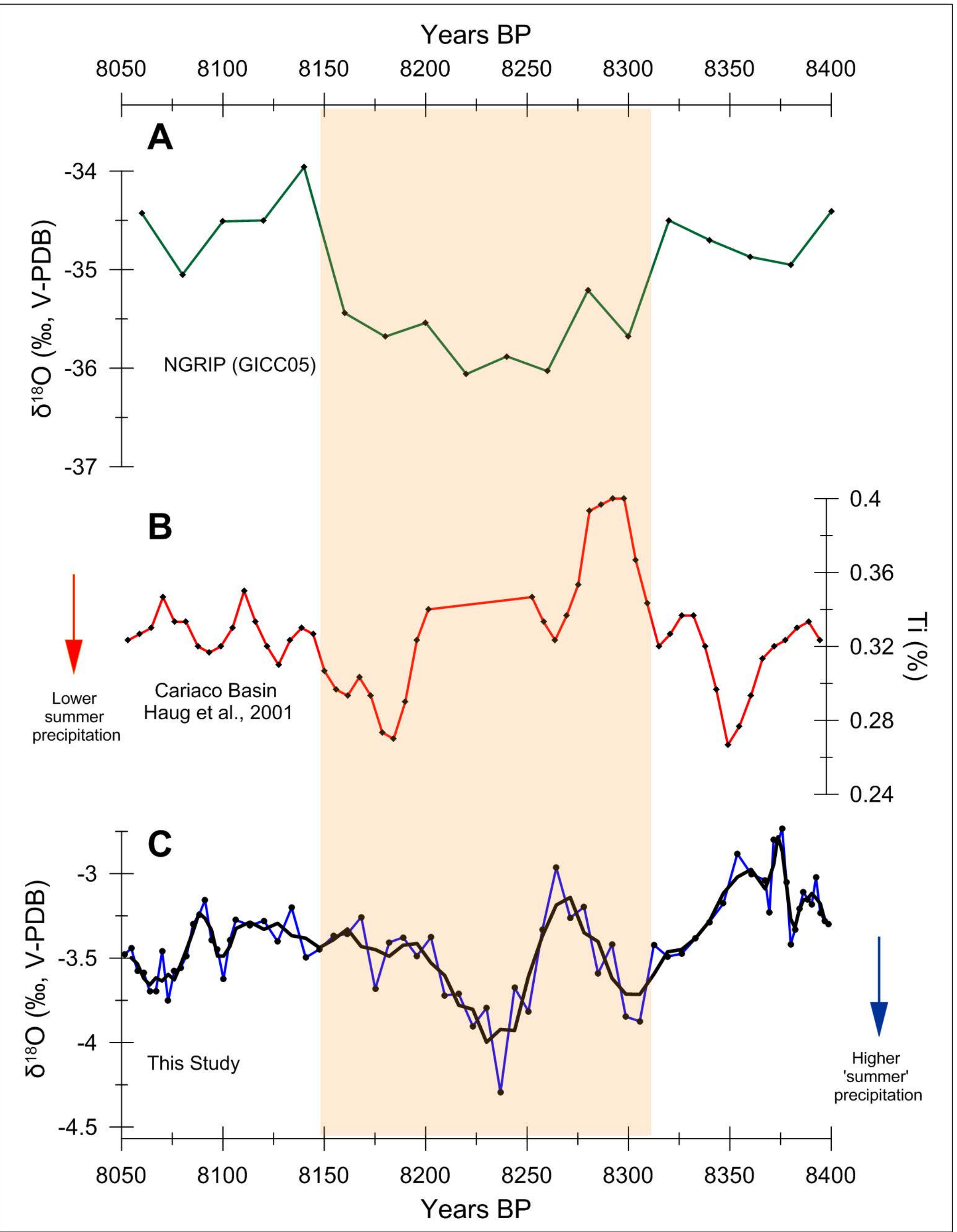

Figure 5 


\section{Years BP}

$\begin{array}{lllllllllll}0 & 200 & 400 & 600 & 800 & 1000 & 1200 & 1400 & 1600 & 1800 & 2000\end{array}$
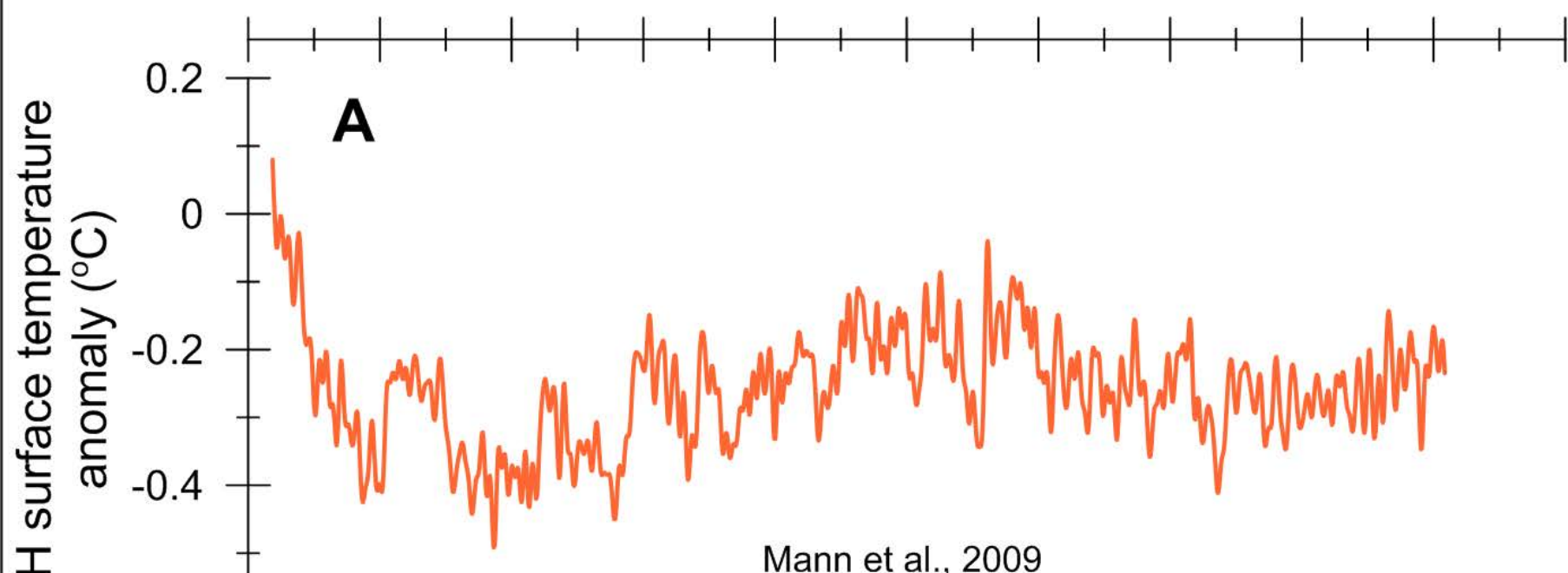

竞 $\quad-0.6$ 工

Mann et al., 2009
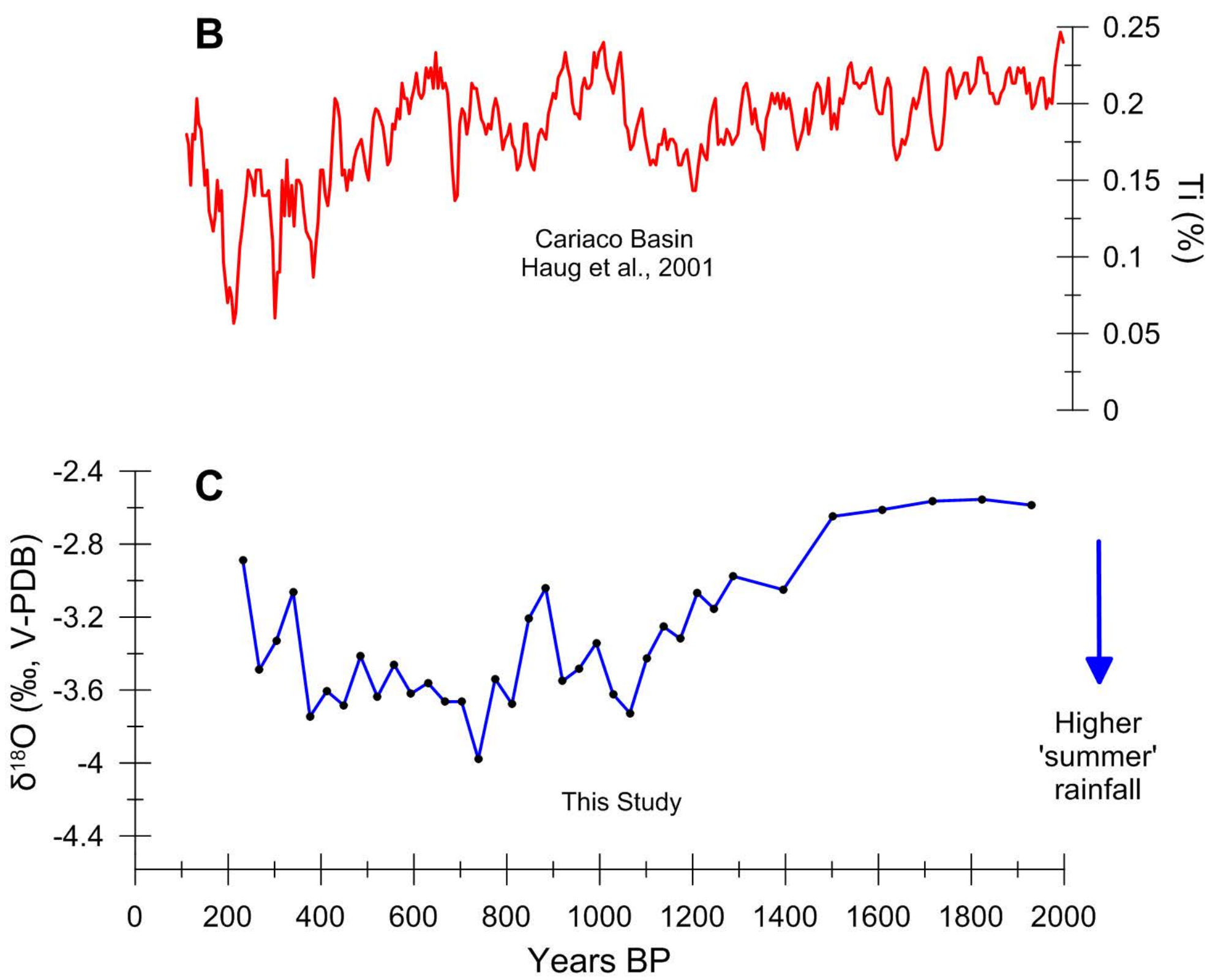